\title{
Coimmobilization of L-asparaginase and glutamate dehydrogenase onto highly activated supports
}

Keywords: Enzyme; Agarose; Structural stabilization; Immobilization; Biochemical engineering; Biomedical engineering

\author{
Victor M. Balcão ${ }^{\mathrm{a}, \mathrm{b}}$, Cesar Mateo $^{\mathrm{c}}$, R. Fernández-Lafuente ${ }^{\mathrm{c}}$, F. Xavier Malcata ${ }^{\mathrm{a}, *}$, \\ José M. Guisán ${ }^{\mathrm{c}}$ \\ ${ }^{a}$ Escola Superior de Biotecnologia, Universidade Católica Portuguesa, Rua Dr. António Bernardino de Almeida, P-4200-072 Porto, Portugal \\ ${ }^{\mathrm{b}}$ Universidade Fernando Pessoa, Praça 9 de Abril, P-4249-004 Porto, Portugal \\ ${ }^{\mathrm{c}}$ Instituto de Catálisis y Petroquímica, CSIC, Campus Universidad Autónoma, Cantoblanco, E-28049 Madrid, Spain
}

\begin{abstract}
In the present research work, production of coimmobilized derivatives of L-asparaginase and glutamate dehydrogenase was attempted. Comparison of immobilization of each enzyme independently with coimmobilization of the two enzymes unfolded important advantages of the latter, namely a decrease in the induction period (time before the maximum reaction rate is virtually achieved) and an increase in the maximum reaction rate. The effectiveness of the independent enzyme derivatives was low; however, it was enhanced by three-fold when the enzymes were coimmobilized onto the same agarose-glutaraldehyde support. Each supporting agarose bead may in fact be viewed as a nano-reactor with in situ reaction and separation (i.e. elimination of the ammonia formed), with the nanoenvironment surrounding each enzyme molecule being essentially devoid of steric hindrance. (c) 2001 Elsevier Science Inc. All rights reserved.
\end{abstract}

\section{Introduction}

L-asparaginase, an enzyme widely used on the clinical level as antitumoral agent, viz. in the treatment of acute leukaemia and lymphosarcoma [1-13], is obtained commercially from Acinetobacter glutaminasificans, Pseudomonas spp., Escherichia coli or Erwinia chrysanthemi; it hydrolyzes L-asparagine into L-aspartic acid and ammonia, a reaction that is essentially irreversible under physiological conditions [10]. Said enzyme is effective against neoplasias that require asparagine and obtain it from circulating plasma pools $[14,15]$, presumably because cancer cells have diminished expression of asparagine synthetase [14]. Of all the aforementioned sources, L-asparaginase from Escherichia coli appears to be a suitable option; it has indeed been comprehensively characterized by chemical and physicochemical methods $[10,14,15]$. In structural terms, its active form is a tetramer [14] of identical subunits [3], each with a molecular weight of $35.6 \mathrm{kDa}$.

\footnotetext{
* Corresponding author.

E-mail address: xmalcata@esb.ucp.pt (F.X. Malcata).
}

Mammalian (bovine liver) glutamate dehydrogenase catalyzes the reversible oxidative deamidation of glutamate to $\alpha$-ketoglutarate and ammonia, using either $\mathrm{NAD}^{+}$or NADH as coenzyme (with comparable efficacies) [16]. Said enzyme is a hexamer of identical subunits, with a total molecular weight of $336 \mathrm{kDa}$. The role in vivo of glutamate dehydrogenase remains controversial: it is thought that it is used in the catalytic step underlying storage of nitrogen in the form of glutamate, which takes place when ammonia levels, at the cell level, are high. Should ammonia levels be low, glutamate dehydrogenase is alternatively used to degrade glutamate to ammonia and $\alpha$-ketoglutarate [16]. The regulation of glutamate levels has a unique importance in the brain, since glutamate is a potent neurotransmitter.

There are three general reasons why immobilized enzymes are desirable, particularly in bioengineering: (i) the enzyme is retained in (or on) the beads (and hence in the bioreactor), which circumvents the need for upstream enzyme makeup and prevents downstream contamination of the product; (ii) immobilized enzymes keep their activity for a longer period than those in solution, because the natural flexibility of the proteinaceous backbone, essential for thermal unimolecular denaturation to take place, is restricted; 
and (iii) enzymes in immobilized form may be deliberately fixed in the vicinity of other enzymes that participate in a given reaction sequence, thereby increasing the overall catalytic efficiency of multistep conversions, because the entropic contribution, arising from the requirement of productive collision of the product(s) of the first reaction with the enzyme catalyzing the second reaction, is dramatically reduced when the reaction becomes intraparticle rather than interparticle [17]. Hence, if two enzymes acting in series are immobilized side by side on a given support matrix, the intermediate product (in our case, ammonia obtained from L-asparagine) has an extremely high probability of reacting further (to produce glutamate) before it can diffuse out of the bead [18].

The current (intrusive) therapy makes use of endovenous administrations of enzymes in soluble form, but is effective only to a certain degree because of two major shortcomings: L-asparaginase circulates in the blood system for only a short time before being taken up and broken down by native proteases; and its presence triggers adverse immunological side-effects, owing to the presence of such alien protein inside the human body, the severity of which may range from mild allergenic reaction to anaphylactic shock.

The development of strategies that will eventually permit structural and functional stabilization of both L-asparaginase and glutamate dehydrogenase via coimmobilization onto highly activated supports may increase the biomedical applicability of these enzymes. In fact, the enzyme-mediated hydrolysis of L-asparagine produces ammonia, which becomes a poison to the human kidney if present in high level; such risk can be easily overcome if another enzyme, possessing a strong preference for ammonia, is coimmobilized together with the former. These coimmobilized derivatives could then be utilized in extracorporeal devices to efficiently eliminate asparagine from the plasma $[19,20]$, without the extra risks incurred in by bulk accumulation of ammonia.

Agarose beads were selected as suitable supports for coimmobilization, since they consist of a biocompatible three-dimensional network of highly hydrophilic and inert fibers; their surface is essentially covered by hydroxyl groups, which can easily be activated for covalent, multisubunit immobilization of enzymes [21-29]. Attachment of the enzyme molecules to the support via short spacer arms, while providing intense enzyme-support interactions, allows full functional stabilization of their multimeric structure because (i) they are prevented from interacting with inactivating microenvironments, (ii) they are protected from the first steps of inactivation, viz. dissociation of subunits and conformational changes, (iii) they are protected from irreversible inactivation through aggregation, (iv) they become much more rigid, so thermal energy-driven vibrations and rotations of hydrogen and disulfide bonds are kept (at most) to a very low level, therefore protecting the enzyme against thermal denaturation, and (v) they are protected against proteolytic attack and action by denaturing (re)agent(s).

\section{Materials and methods}

\subsection{Materials}

2.1a. Enzymes. The enzymes used were L-asparaginase (type II) from Escherichia coli, purchased in a 50\% (v/v) glycerol suspension from Fluka (Steinheim, Germany), and glutamate dehydrogenase from bovine liver, purchased in a $50 \%(\mathrm{v} / \mathrm{v})$ glycerol suspension from Boehringer Mannheim (Mannheim, Germany).

2.1b. Chemicals. Agarose beads ( $4 \%$ cross-linked) were obtained from HISPANAGAR (Burgos, Spain). Glycidol (2,3epoxy-1-propanol), L-asparagine monohydrate, $\beta$-NADH, boric acid, ethylenediamine, formaldehyde, TRIZMA ${ }^{\circledR} \mathrm{Hy}-$ drochloride, Schiff's reagent (fuchsin-sulfate), sodium acetate trihydrate and sodium borohydride were all purchased from Sigma (St. Louis, MO, U.S.A.). $\alpha$-Ketoglutarate, in disodium salt form, was purchased from Boehringer Mannheim. Sodium metaperiodate was purchased from Merck (Darmstadt, Germany). Sodium hydroxide, sodium hydrogen phosphate (monohydrate) and glycerol $(87 \%(\mathrm{v} / \mathrm{v})$ in water) were all purchased from Panreac Química (Barcelona, Spain). Glutaraldehyde (25\% (v/v) in water) was purchased from Fluka. Tap water was purified in a Milli-Q Plus 185 system (Molsheim, France) to a final conductivity of ca. $18.2 \mathrm{M} \Omega \cdot \mathrm{cm}^{-1}$.

2.1c. Analytical equipment. All spectrophotometric readings were carried out at $25^{\circ} \mathrm{C}$ using quartz cuvettes, in a UVIKON 930 UV-VIS spectrophotometer coupled with a KP91-00580 magnetic stirrer unit for the cuvette (Kontron Instruments, Madrid, Spain).

\section{Experimental procedures}

\subsection{Activity assay for L-asparaginase}

The activity assay developed for L-asparaginase is based on the production of ammonia during hydrolysis of Lasparagine, which is then degraded by glutamate dehydrogenase with concomitant oxidation of $\beta-\mathrm{NADH}$; depletion of $\beta-\mathrm{NADH}$ is then monitored spectrophotometrically at $340 \mathrm{~nm}$. Improved assay conditions comprise the addition, to a quartz cuvette containing a magnetic rod, of the following sequence of reactants: $2 \mathrm{~mL}$ of an aqueous solution $50 \mathrm{mM}$ in $\mathrm{NaH}_{2} \mathrm{PO}_{4}(\mathrm{pH} 7), 1.1 \mathrm{mM}$ in L-asparagine and $0.11 \mathrm{mM}$ in $\alpha$-ketoglutarate; $25 \mu \mathrm{L}$ of an aqueous solution $50 \mathrm{mM}$ in $\mathrm{NaH}_{2} \mathrm{PO}_{4}$ (pH 7) and $43.4 \mathrm{mM}$ in $\beta-\mathrm{NADH}$; and $50 \mu \mathrm{L}$ of an aqueous solution $50 \mathrm{mM}$ in $\mathrm{NaH}_{2} \mathrm{PO}_{4}(\mathrm{pH} 7)$, $50 \%(\mathrm{v} / \mathrm{v})$ in glycerol and $8.81 \mu \mathrm{M}$ in glutamate dehydrogenase. The mixture in the cuvette, thermostatted at $25^{\circ} \mathrm{C}$, was gently stirred for ca. 3 min. The activity assay was initiated by addition into the cuvette of an aliquot of $100 \mu \mathrm{L}$ of the L-asparaginase solution which is to be tested for 
activity (typically with a protein concentration of $3.86 \times$ $10^{-8} \mathrm{M}$ ); immediately thereafter, absorbance at $340 \mathrm{~nm}$ was read up to $10 \mathrm{~min}$. Since the activity of L-asparaginase is directly proportional to the rate of production of ammonia, and since the large excess of glutamate dehydrogenase degrades it totally with concomitant oxidation of $\beta$-NADH, the (negative) slope of the linear portion of the plot of absorbance versus reaction time provides a measure of the activity of L-asparaginase.

\subsection{Activity assay for glutamate dehydrogenase}

The activity assay for glutamate dehydrogenase is based on the degradation of ammonia, and concomitant oxidation of $\beta$-NADH. Since there is only one enzyme involved in this assay, there is no need for it to proceed rapidly, so a relatively small amount of glutamate dehydrogenase can be used. This enzymatic activity assay is also based on the depletion of $\beta-\mathrm{NADH}$, monitored at $340 \mathrm{~nm}$. The assay, after careful tuning, comprises the sequential addition, to a quartz cuvette containing a magnetic rod, of the following reactants: $2 \mathrm{~mL}$ of an aqueous solution $50 \mathrm{mM}$ in $\mathrm{NaH}_{2} \mathrm{PO}_{4}$ (pH 7), $1.1 \mathrm{mM}$ in $\mathrm{NH}_{4} \mathrm{Cl}$ and $0.11 \mathrm{mM}$ in $\alpha$-ketoglutarate; and $50 \mu \mathrm{L}$ of an aqueous solution $50 \mathrm{mM}$ in $\mathrm{NaH}_{2} \mathrm{PO}_{4}(\mathrm{pH}$ 7) and $21.7 \mathrm{mM}$ in $\beta$-NADH. The mixture in the cuvette, under magnetic stirring, is thermostatted at $25^{\circ} \mathrm{C}$ for ca. 3 min, and the activity assay is initiated by addition into the cuvette of an aliquot of $200 \mu \mathrm{L}$ of the glutamate dehydrogenase solution, which is to be tested for activity (typically with a protein concentration of $2.20 \times 10^{-7} \mathrm{M}$ ). Immediately after addition of the enzyme solution, absorbance at $340 \mathrm{~nm}$ was read during up to $10 \mathrm{~min}$. Since the activity of glutamate dehydrogenase is directly proportional to the rate of consumption of ammonia, and therefore to the rate of disappearance of $\beta-\mathrm{NADH}$, the negative slope of the linear part of the plot of absorbance versus reaction time provides a measure of the activity of glutamate dehydrogenase.

\subsection{Activity assay for coacting L-asparaginase and glutamate dehydrogenase}

The activity assay for the solutions containing both enzymes was again based on the degradation of ammonia, and subsequent oxidation of $\beta$-NADH. The optimized bienzymatic activity assay is thus based on the rate of disappearance of $\beta$-NADH, monitored at $340 \mathrm{~nm}$. The carefully tuned assay comprises the addition, to a quartz cuvette containing a magnetic rod, of $2 \mathrm{~mL}$ of an aqueous solution $50 \mathrm{mM}$ in $\mathrm{NaH}_{2} \mathrm{PO}_{4}, 1.1 \mathrm{mM}$ in L-asparagine, $0.11 \mathrm{mM}$ in $\alpha$-ketoglutarate and $0.5 \mathrm{mM}$ in $\beta-\mathrm{NADH}$. The mixture in the cuvette, under magnetic stirring, is thermostatted at $25^{\circ} \mathrm{C}$ for ca. 3 $\mathrm{min}$, and the activity assay is initiated by addition into the cuvette of an aliquot of $200 \mu \mathrm{L}$ of the bienzymatic solution, which is to be tested for activity. Immediately after addition of this latter solution, absorbance at $340 \mathrm{~nm}$ was read during up to $10 \mathrm{~min}$.

\subsection{Preparation of supports for immobilization}

3.4a. Glyoxyl-agarose supports. The procedure described by Guisán (1988) [21] was followed, with slight modifications: $105 \mathrm{~g}$ of agarose beads (cross-linked to $4 \%$, and previously washed with plenty of deionized water) were weighed into a plastic flask, and water was added to a final volume of $180 \mathrm{~mL}(0.7 \mathrm{~g}$ of agarose is roughly equivalent to $1 \mathrm{~mL}$ ). Following mild homogenization, $50 \mathrm{~mL}$ of $1.7 \mathrm{M}$ $\mathrm{NaOH}$ containing $1.425 \mathrm{~g} \mathrm{NaBH}_{4}$ (as reducing agent) was slowly added. The flask was then placed in an ice bath, and glycidol was added dropwise (because it promotes a highly exothermic reaction) to a final concentration of $2 \mathrm{M}$. The mixture was then paddle-agitated at room temperature (ca. $25^{\circ} \mathrm{C}$ ) for $15-18 \mathrm{~h}$, and the gel was finally washed with excess deionized water. The activated gel (i.e. $150 \mathrm{~mL}_{\text {gel }}$ ) thus obtained was added with $1 \mathrm{~mL}$ of aqueous $100 \mathrm{mM} \mathrm{NaIO}$ per $\mathrm{mL}$ of gel (so as to reach $100 \mu \mathrm{mol}_{\text {aldehyde groups }} / \mathrm{mL}_{\text {gel }}$ ). The gel was then suspended (1:10) in water to a final volume of $1500 \mathrm{~mL}$, and oxidation was allowed to proceed for $1.5-2 \mathrm{~h}$ with paddle agitation; then, the gel was washed with plenty of deionized water. Confirmation of the presence of aldehyde groups in the gel was by addition of a few $\mathrm{mg}$ of (oxidized) gel to ca. $200 \mu \mathrm{L}$ of Schiff's reagent in an eppendorf, which produced the expected pinky-purple coloration.

3.4b. Agarose-glutaraldehyde supports. The procedure described by Guisán (1988) [21] was again followed, with slight modifications: $70 \mathrm{~g}$ of glyoxyl-agarose gel (prepared according to the procedure described above) was weighed into a plastic beaker, and further added with $400 \mathrm{~mL}$ of $2 \mathrm{M}$ ethylenediamine ( $\mathrm{pH} 10)$. Following mild paddle agitation for ca. $2 \mathrm{~h}, 4 \mathrm{~g}$ of $\mathrm{NaBH}_{4}$ was added and the paddle agitation was provided for an extra $2 \mathrm{~h}$. The amine gel thus obtained was then sequentially washed with $1000 \mathrm{~mL}$ of $0.1 \mathrm{M}$ sodium acetate ( $\mathrm{pH} 4$ ) (to eliminate sodium borohydride), $1000 \mathrm{~mL}$ of $0.1 \mathrm{M}$ boric acid (pH 9) (to reduce electrostatic interactions and eliminate excess ethylenediamine), and finally plenty of deionized water. To $5 \mathrm{~g}$ of amine gel, $5.6 \mathrm{~mL}$ of $200 \mathrm{mM} \mathrm{NaH}{ }_{2} \mathrm{PO}_{4}$ was added, and the $\mathrm{pH}$ of the resulting mixture was adjusted to 7 using diluted $\mathrm{NaOH} ; 8.4 \mathrm{~mL}$ of aqueous $25 \%(\mathrm{v} / \mathrm{v})$ glutaraldehyde was then added and the $\mathrm{pH}$ adjusted once again to 7 . The mixture was subsequently paddle-agitated overnight, and the final gel was washed with excess deionized water.

\subsection{Immobilization protocols}

3.5a. Preparation of immobilized L-asparaginase. The preparation of these immobilized derivatives followed the procedure described by Balcão et al. (2001), [29] and encompassed addition of $16 \mathrm{~mL}$ aqueous $87 \%(\mathrm{v} / \mathrm{v})$ glycerol onto a plastic flask, followed by homogenization with 16 $\mathrm{mL}$ of $25 \mathrm{mM} \mathrm{NaH}_{2} \mathrm{PO}_{4}$ (pH 7). To the resulting solution, $229 \mu \mathrm{L}$ of a $4.2 \mathrm{mg}_{\mathrm{L} \text {-asparaginase }} / \mathrm{mL}_{\text {glycerol }}$ suspension was 
added. Following mild homogenization, $2 \mathrm{~g}$ of agaroseglutaraldehyde (after activation with $40 \mu \mathrm{mol}_{\text {aldehyde groups }}{ }$ $\mathrm{mL}_{\mathrm{gel}}$ ) was added, and the flask was stoppered tightly and placed in an orbital shaker at $4^{\circ} \mathrm{C}$. Samples of both the suspension and the supernatant were regularly withdrawn and assayed for activity, together with the blank (which consisted of a $4 \mathrm{~mL}$-sample of enzyme solution, withdrawn prior to addition of the support). The immobilization procedure was terminated after 45 min by simply washing the derivative with plenty of deionized water, resuspending it in aqueous $50 \mathrm{mM} \mathrm{NaH}_{2} \mathrm{PO}_{4}(\mathrm{pH} 7)$ at $4{ }^{\circ} \mathrm{C}$, and storing the suspension in an ice bath.

3.5b. Preparation of immobilized glutamate dehydrogenase. The preparation of these immobilized derivatives encompassed addition of $16 \mathrm{~mL}$ aqueous $87 \%$ (v/v) glycerol into a plastic flask, followed by homogenization with $16 \mathrm{~mL}$ of 25 $\mathrm{mM} \mathrm{NaH}{ }_{2} \mathrm{PO}_{4}(\mathrm{pH} 7)$ at $4^{\circ} \mathrm{C}$. To the resulting solution, 5200 $\mu \mathrm{L}$ of a $10 \mathrm{mg}_{\text {glutamate dehydrogenase }} / \mathrm{mL}_{\text {glycerol }}$ suspension was added. Following mild homogenization, $2 \mathrm{~g}$ of agaroseglutaraldehyde (after activation with $40 \mu \mathrm{mol}_{\text {aldehyde groups }}$ ' $\mathrm{mL}_{\mathrm{gel}}$ ) was added, and the flask was stoppered tightly and placed in an orbital shaker at $4^{\circ} \mathrm{C}$. Samples of both the suspension and the supernatant were regularly withdrawn and assayed for activity, together with the blank (which consisted of a $4 \mathrm{~mL}$-sample of enzyme solution, withdrawn prior to addition of the support). The immobilization procedure was terminated after 45 min by simply washing the derivative with plenty of deionized water, resuspending it in $50 \mathrm{mM} \mathrm{NaH}_{2} \mathrm{PO}_{4}(\mathrm{pH} 7)$ at $4{ }^{\circ} \mathrm{C}$, and storing the suspension in an ice bath.

3.5c. Preparation of coimmobilized L-asparaginase and glutamate dehydrogenase. The preparation of these coimmobilized derivatives encompassed addition of $16 \mathrm{~mL}$ of aqueous $87 \%(\mathrm{v} / \mathrm{v})$ glycerol into a plastic flask, followed by homogenization with $16 \mathrm{~mL}$ of $25 \mathrm{mM} \mathrm{NaH}_{2} \mathrm{PO}_{4}(\mathrm{pH} 7)$. To the resulting solution, $229 \mu \mathrm{L}$ of a $4.2 \mathrm{mg}_{\mathrm{L} \text {-asparaginase }} / \mathrm{mL}_{\text {glycerol }}$ suspension and $457 \mu \mathrm{L}$ of a $10 \mathrm{mg}_{\text {glutamate dehydrogenase }}$ / $\mathrm{mL}_{\text {glycerol }}$ suspension were added to produce a 1:1 enzyme mixture of the resulting derivative. Following mild homogenization, $2 \mathrm{~g}$ of agarose-glutaraldehyde (after activation with $40 \mu \mathrm{mol}_{\text {aldehyde groups }} / \mathrm{mL}_{\text {gel }}$ ) was added, and the flask was stoppered tightly and placed in an orbital shaker at $4^{\circ} \mathrm{C}$. Samples of both the suspension and the supernatant (i.e. bienzymatic solutions) were regularly withdrawn and assayed for activity, together with the blank (which consisted of a $4 \mathrm{~mL}$-sample of solution containing both enzymes, withdrawn prior to addition of the support). After $30 \mathrm{~min}$ of contacting the bienzymatic solution with the support, the immobilization procedure was terminated by simply washing the derivative with plenty of deionized water; it was then resuspended in cold $50 \mathrm{mM} \mathrm{NaH} \mathrm{PO}_{4}(\mathrm{pH} 7)$, and the resulting suspension was kept in an ice bath. This procedure was repeated when preparing other coimmobilized derivatives: using $229 \mu \mathrm{L}$ of $4.2 \mathrm{mg}_{\mathrm{L} \text {-asparaginase }} / \mathrm{mL}_{\text {glycerol }}$ suspen- sion and $2285 \mu \mathrm{L}$ of $10 \mathrm{mg}_{\text {glutamate dehydrogenase }} / \mathrm{mL}_{\text {glycerol }}$ suspension to produce a 1:5 enzyme mixture of L-asparaginase and glutamate dehydrogenase in the resulting derivative; using $58 \mu \mathrm{L}$ of $4.2 \mathrm{mg}_{\mathrm{L}-\text { asparaginase }} / \mathrm{mL}_{\text {glycerol }}$ suspension and $2285 \mu \mathrm{L}$ of $10 \mathrm{mg}_{\text {glutamate dehydrogenase }} / \mathrm{mL}_{\text {glycerol }}$ suspension to produce a 1:20 enzyme mixture of L-asparaginase and glutamate dehydrogenase in the resulting derivative; or using $12 \mu \mathrm{L}$ of $4.2 \mathrm{mg}_{\mathrm{L} \text {-asparaginase }} / \mathrm{mL}_{\text {glycerol }}$ suspension and $2285 \mu \mathrm{L}$ of $10 \mathrm{mg}_{\text {glutamate dehydrogenase }} /$ $\mathrm{mL}_{\text {glycerol }}$ suspension to produce a 1:100 enzyme mixture of L-asparaginase and glutamate dehydrogenase in the resulting derivative.

\subsection{Conversion of L-asparagine to glutamate}

3.6a. Reactions using independent immobilized enzymes. Since reduction of the independent derivatives after the immobilization procedure proved deleterious for the immobilized enzymes, both independent derivatives were immediately resuspended in cold phosphate buffer $(50 \mathrm{mM}, \mathrm{pH} 7)$ and further kept in ice. The derivatives were not reduced with sodium borohydride, so the enzyme continued interacting with the support; however, the low temperature slowed down the reactional consequence of such interactions. Independent derivatives were resuspended using two dilution factors for L-asparaginase, viz. 1:10 $(200 \mathrm{mg}$ derivative $+2.9 \mathrm{~mL}$ of $50 \mathrm{mM} \mathrm{NaH}_{2} \mathrm{PO}_{4}$, $\mathrm{pH} 7$, at $4^{\circ} \mathrm{C}$ ) and 1:20 (200 mg coimmobilized derivative $+5.8 \mathrm{~mL}$ of 50 $\mathrm{mM} \mathrm{NaH}{ }_{2} \mathrm{PO}_{4}, \mathrm{pH} 7$, at $4{ }^{\circ} \mathrm{C}$ ), and two dilution factors for glutamate dehydrogenase, viz. 1:10 (700 mg derivative + $10 \mathrm{~mL}$ of $\left.50 \mathrm{mM} \mathrm{NaH}{ }_{2} \mathrm{PO}_{4}, \mathrm{pH} 7,4^{\circ} \mathrm{C}\right)$ and $1: 100(700 \mathrm{mg}$ coimmobilized derivative $+100 \mathrm{~mL}$ of $50 \mathrm{mM} \mathrm{NaH}_{2} \mathrm{PO}_{4}$, $\left.\mathrm{pH} 7,4^{\circ} \mathrm{C}\right)$. Reactions were performed by employing variable amounts of both (independent) enzyme derivatives. The reaction vessel was a quartz cuvette containing a magnetic rod and thermostatted at $25^{\circ} \mathrm{C}$; the reaction medium encompassed $2 \mathrm{~mL}$ of an aqueous solution of $50 \mathrm{mM}$ $\mathrm{NaH}_{2} \mathrm{PO}_{4}$ (pH 7), $1.1 \mathrm{mM}$ L-asparagine, $0.11 \mathrm{mM} \alpha$-ketoglutarate and $0.5 \mathrm{mM} \beta-\mathrm{NADH}$. To the reaction medium, the designated amount of glutamate dehydrogenase-derivative suspension was added, and the reaction was initiated with the subsequent addition of the designated amount of L-asparaginase-derivative suspension. The in situ production of ammonia (following hydrolysis of L-asparagine by the L-asparaginase derivative) and its degradation by the glutamate dehydrogenase-derivative, with consequent oxidation (and hence depletion) of $\beta-\mathrm{NADH}$, was monitored at $340 \mathrm{~nm}$ for ca. $20 \mathrm{~min}$.

3.6b. Reactions using coimmobilized enzymes. Coimmobilized derivatives were resuspended according to two dilution factors, viz. 1:5 (100 mg coimmobilized derivative + $715 \mu \mathrm{L}$ of $50 \mathrm{mM} \mathrm{NaH} \mathrm{PO}_{4}, \mathrm{pH} \mathrm{7}$, at $\left.4^{\circ} \mathrm{C}\right)$ and 1:10 (100 $\mathrm{mg}$ coimmobilized derivative $+1430 \mu \mathrm{L}$ of $50 \mathrm{mM}$ $\mathrm{NaH}_{2} \mathrm{PO}_{4}, \mathrm{pH} 7$, at $4^{\circ} \mathrm{C}$ ). The reaction vessel was again a quartz cuvette containing a magnetic rod thermostatted at 

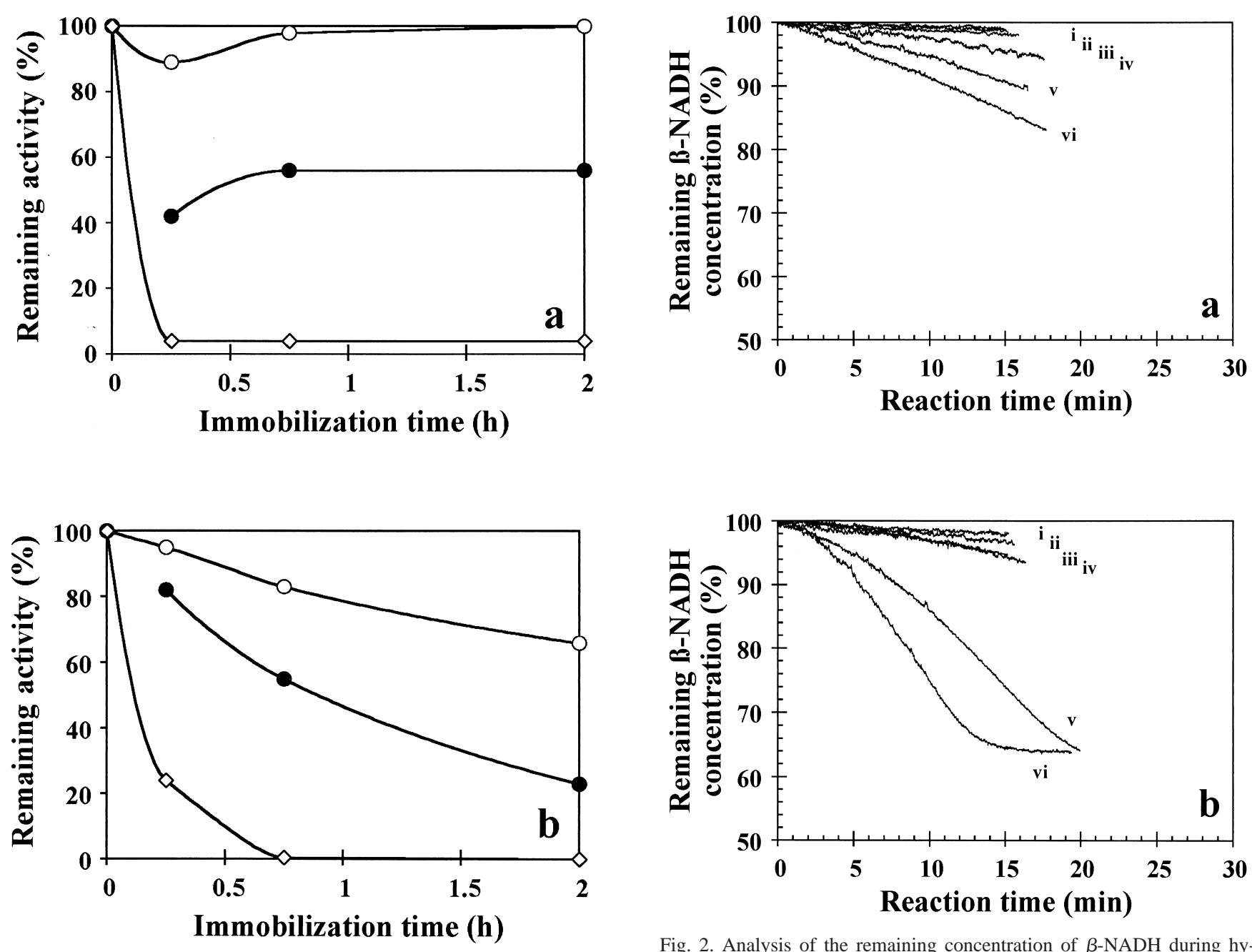

Fig. 2. Analysis of the remaining concentration of $\beta$-NADH during hydrolysis of L-asparagine with (a) $2.4 \mu \mathrm{L}$ independent L-asparaginase gel and various amounts of independent glutamate dehydrogenase gel (viz. i: $0.5 \mu \mathrm{L}$; ii: $1 \mu \mathrm{L}$; iii: $2 \mu \mathrm{L}$; iv: $5 \mu \mathrm{L}$; v: $20 \mu \mathrm{L}$; and vi: $40 \mu \mathrm{L}$ ), and (b) 18 $\mu \mathrm{L}$ independent $\mathrm{L}$-asparaginase gel and various amounts of independent glutamate dehydrogenase gel (viz. i: $0.5 \mu \mathrm{L}$; ii: $1 \mu \mathrm{L}$; iii: $2 \mu \mathrm{L}$; iv: $5 \mu \mathrm{L}$; v: $20 \mu \mathrm{L}$; and vi: $40 \mu \mathrm{L}$ ).

$25^{\circ} \mathrm{C}$; the reaction medium encompassed $2 \mathrm{~mL}$ of an aqueous solution of $50 \mathrm{mM} \mathrm{NaH} \mathrm{PO}_{4}(\mathrm{pH} 7), 1.1 \mathrm{mM} \mathrm{L}-$ asparagine, $0.11 \mathrm{mM} \quad \alpha$-ketoglutarate and $0.5 \mathrm{mM}$ $\beta$-NADH. The reaction was initiated with addition of variable amounts of coimmobilized derivative suspension. The in situ production of ammonia (following hydrolysis of L-asparagine by the coimmobilized L-asparaginase) and its degradation by coimmobilized glutamate dehydrogenase, with consequent oxidation (and hence depletion) of $\beta$-NADH, was monitored at $340 \mathrm{~nm}$ for ca. $20 \mathrm{~min}$.

Fig. 1. Analysis of the remaining activity of L-asparaginase (a), glutamate dehydrogenase (b), and coacting L-asparaginase and glutamate dehydrogenase (c) during immobilization onto agarose-glutaraldehyde supports activated with $40 \mu \mathrm{mol}_{\text {aldehyde groups }} / \mathrm{mL}_{\text {gel }}$. Data points represent the percentage activity of the blank $(\bigcirc)$, the suspension $(\bullet)$ and the supernatant $(\diamond)$, for immobilization of independent enzymes, and 1:1 ( $\square$ ), 1:5 (圆),

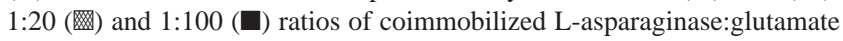
dehydrogenase.

\section{Results and Discussion}

4.0a. Independent enzyme immobilization. Agarose-based supports, pre-activated with glutaraldehyde, react preferentially with the terminal amino residues of proteins. When 

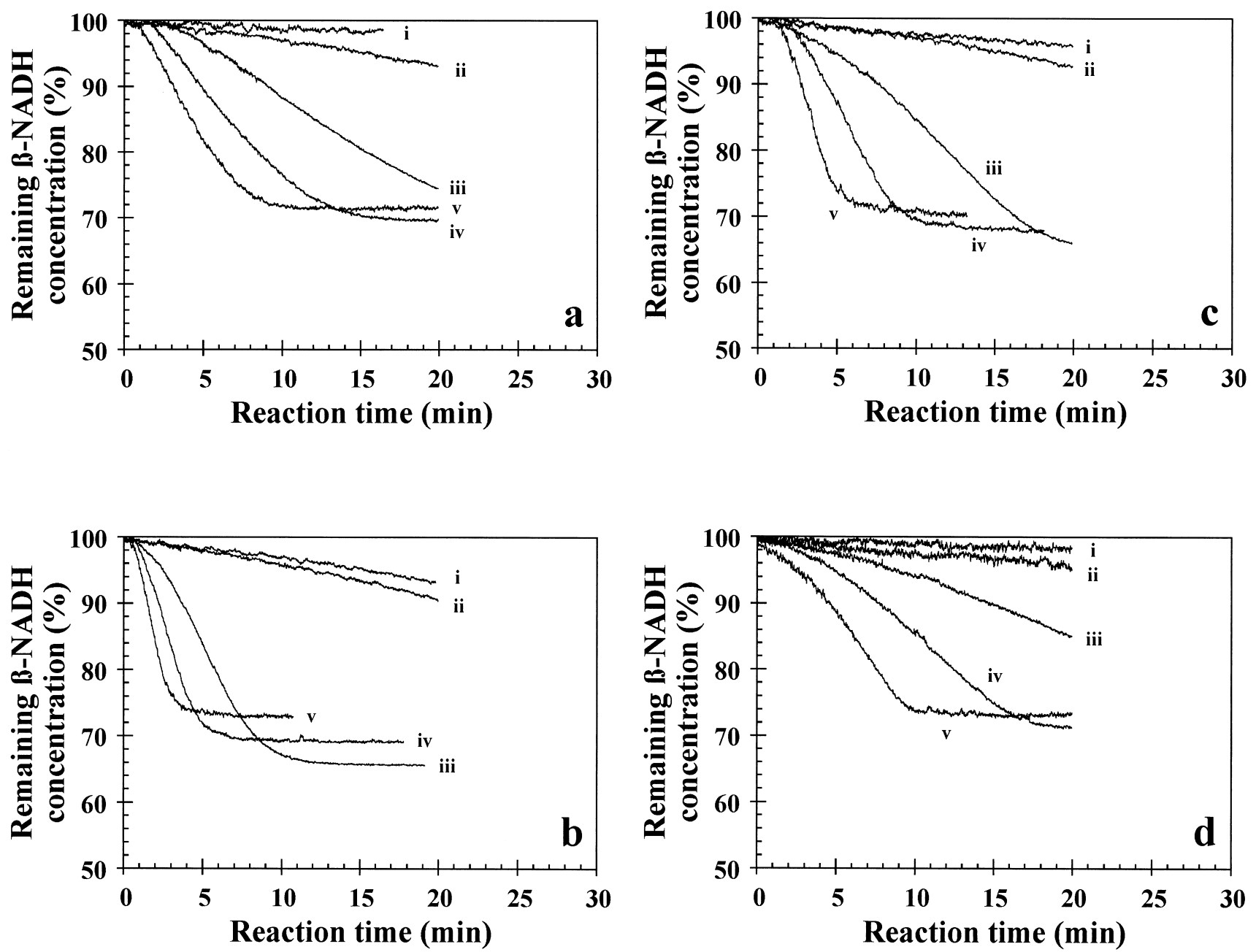

Fig. 3. Analysis of the remaining concentration of $\beta$-NADH during hydrolysis of L-asparagine with (a) various amounts of coimmobilized 1:1 gel (viz. i: $2.5 \mu \mathrm{L}$; ii: $5 \mu \mathrm{L}$; iii: $20 \mu \mathrm{L}$; iv: $50 \mu \mathrm{L}$; and v: $100 \mu \mathrm{L}$ ), (b) various amounts of coimmobilized 1:5 gel (viz. i: $2.5 \mu \mathrm{L}$; ii: $5 \mu \mathrm{L}$; iii: $20 \mu \mathrm{L}$; iv: $50 \mu \mathrm{L}$; and v: $100 \mu \mathrm{L}$ ), (c) various amounts of coimmobilized 1:20 gel (viz. i: $2.5 \mu \mathrm{L}$; ii: $5 \mu \mathrm{L}$; iii: $20 \mu \mathrm{L}$; iv: $50 \mu \mathrm{L}$; and v: $100 \mu \mathrm{L}$ ), and (d) various amounts of coimmobilized 1:100 gel (viz. i: $2.5 \mu \mathrm{L}$; ii: $5 \mu \mathrm{L}$; iii: $20 \mu \mathrm{L}$; iv: $50 \mu \mathrm{L}$; and v: $100 \mu \mathrm{L}$ ).

the activation degree is high, as was the case, and the enzyme is allowed to contact the support for a long time (say, above $2 \mathrm{~h}$ ) in an environment set at low ionic strength, several bonds will be established between enzyme and support $[27,30]$; the establishment of new bonds between those two highly complex structures requires longer reaction times [27], possibly because of difficulties in aligning correctly the enzyme surface and the activated groups on the support surface. The activity of the free L-asparaginase solution (see Figure 1a) remained virtually constant during the timeframe of the immobilization trials. Furthermore, the percent activity retained by the derivative was $52 \%$, whereas the blank exhibited its full initial activity. These results are in close agreement with those reported by Fernández-Lafuente et al. (1999), Blanco and Guisán (1989), and Blanco et al. (1989) [27,30,31].

Bearing in mind that glutamate dehydrogenase must be in great excess in the reaction medium, an independent derivative of this enzyme was prepared, but making a large excess of enzyme available to the support. The results obtained during the timeframe of the immobilization procedure are displayed in Figure 1b. As can be observed, glutamate dehydrogenase is immobilized fast at low ionic strength. However, the suspension lose activity as time elapsed, probably because more bonds formed as more enzyme molecules became attached. This could promote a slight distortion in the three-dimensional architecture of the enzyme, thereby inactivating some of the enzyme molecules already immobilized. For this reason, the independent derivatives of glutamate dehydrogenase were further prepared simply by contacting the enzyme with the support for 45 min. This procedure led to glutamate dehydrogenase derivatives that retained more than $50 \%$ of the activity of the initial (free) enzyme solution (see Figure 1b).

4.0b. Enzyme coimmobilization. As can be realized from inspection of Figure 1c, the activity of the free enzyme solution (i.e. the supernatant) decays appreciably during the 
Table 1

Maximum reaction rates $\left(\vartheta_{\max }\right)$ using distinct amounts of coimmobilized enzymes L-asparaginase (L-asnase) and glutamate dehydrogenase (GDH)

\begin{tabular}{|c|c|c|c|c|}
\hline \multirow{3}{*}{$\begin{array}{l}\text { Amount of } \\
\text { coimmobilized } \\
\text { derivative }\end{array}$} & \multicolumn{4}{|c|}{$\vartheta_{\max }\left(\mu \mathrm{mol}_{\mathrm{NH}_{4}}+/ \mathrm{min}\right.$, at $25^{\circ} \mathrm{C}$ and $\left.\mathrm{pH} 7\right)$} \\
\hline & \multicolumn{4}{|c|}{ Ratio of L-asnase: GDH } \\
\hline & $1: 1$ & $1: 5$ & $1: 20$ & $1: 100$ \\
\hline $2.5 \mu \mathrm{L}$ & 0.0039 & 0.0105 & 0.0053 & 0.0017 \\
\hline $5 \mu \mathrm{L}$ & 0.0071 & 0.0073 & 0.0081 & 0.0043 \\
\hline $20 \mu \mathrm{L}$ & 0.0399 & 0.1139 & 0.0508 & 0.0153 \\
\hline $50 \mu \mathrm{L}$ & 0.0700 & 0.1765 & 0.1001 & 0.0424 \\
\hline $100 \mu \mathrm{L}$ & 0.1184 & 0.3119 & 0.1913 & 0.0835 \\
\hline
\end{tabular}

time frame of the immobilization protocol, for all coimmobilization proportions. By the end of the coimmobilization timeframe, the percent activity of the enzyme derivative is ca. $45 \%$ (obtained as the difference between the activity of the suspension and that of the supernatant) for the $1: 1$ derivative, $65 \%$ for the $1: 5$ derivative, $50 \%$ for the $1: 20$ derivative and $41 \%$ for the $1: 100$ derivative, whereas the blank exhibited ca. 94\% (1:1), 90\% (1:5), 96\% (1:20) and $100 \%$ (1:100), respectively, of the initial activity (see Figure $1 \mathrm{c})$; this implies that the coimmobilized derivatives retained ca. $42 \%$ (for the $1: 1$ derivative), $59 \%$ (for the $1: 5$ ), $48 \%$ (for the $1: 20$ ) and $41 \%$ (for the $1: 100$ ) of the initial activity of the bienzymatic solution.

When performing this type of enzyme immobilization, it is usually necessary to reduce the derivative upon completion of the immobilization procedure; this will convert the non-reacted groups on the surface of the support into inert hydroxyl groups, which ensures that the immobilized enzyme molecules will not interact further with such groups. In our case, however, the coimmobilized derivatives lost all activity after reduction with sodium borohydride and washing with deionized water (results not shown). At first glance, two possible explanations appear plausible: reduction of the coimmobilized derivatives may have inactivated one (or both) enzymes, or one of the enzymes might have adsorbed competitively with the other enzyme that was already immobilized, thus allowing it to be bleached away during
Table 2

Maximum reaction rates $\left(\vartheta_{\max }\right)$ using distinct amounts of independent immobilized enzymes L-asparaginase (L-asnase) and glutamate dehydrogenase $(\mathrm{GDH})$

\begin{tabular}{lcl}
\hline $\begin{array}{l}\text { Amount of L-asnase } \\
\text { derivative }\end{array}$ & $\begin{array}{l}\text { Amount of GDH } \\
\text { derivative }\end{array}$ & $\begin{array}{l}\vartheta_{\max }\left(\mu \mathrm{mol}_{\mathrm{NH}_{4}}+/ \mathrm{min},\right. \\
\left.\text { at } 25^{\circ} \mathrm{C} \text { and } \mathrm{pH} 7\right)\end{array}$ \\
\hline $2.4 \mu \mathrm{L}$ & $0.5 \mu \mathrm{L}$ & 0.0027 \\
1 & $\mu \mathrm{L}$ & 0.0042 \\
2 & $\mu \mathrm{L}$ & 0.0031 \\
5 & $\mu \mathrm{L}$ & 0.0059 \\
20 & $\mu \mathrm{L}$ & 0.0147 \\
40 & $\mu \mathrm{L}$ & 0.0202 \\
$18 \mu \mathrm{L}$ & $0.5 \mu \mathrm{L}$ & 0.0035 \\
1 & $\mu \mathrm{L}$ & 0.0048 \\
2 & $\mu \mathrm{L}$ & 0.0060 \\
5 & $\mu \mathrm{L}$ & 0.0090 \\
20 & $\mu \mathrm{L}$ & 0.0408 \\
40 & $\mu \mathrm{L}$ & 0.0708 \\
\hline
\end{tabular}

washing; this second hypothesis seems unlikely because it would be necessary that all enzyme molecules of one kind would be exchanged in the adsorption sites of all enzyme molecules of the other kind. Following the first, more probable hypothesis, it was decided not to reduce the coimmobilized derivatives upon completion of the immobilization procedure; instead, one resuspended them in buffer, at $4^{\circ} \mathrm{C}$, followed by storage in ice (as the low temperature will slow down further interactions between attached enzyme molecules and non-reacted groups on the surface of the support) before performing the experiments.

4.0c. Performance of independent immobilized enzymes. The results, in the form of remaining $\beta$-NADH concentration, obtained for the batch hydrolysis of L-asparagine using independent derivatives of L-asparaginase and glutamate dehydrogenase, are displayed in Figure 2a for $2.4 \mu \mathrm{L}$ of the $\mathrm{L}$-asparaginase derivative and variable amounts of the glutamate dehydrogenase derivative, and in Figure $2 \mathrm{~b}$ for 18 $\mu \mathrm{L}$ of the L-asparaginase derivative and the same variable amounts of the glutamate dehydrogenase derivative.

Table 3

Maximum reaction rates $\left(\mu \mathrm{mol}_{\mathrm{NH}_{4}}+/ \mathrm{min}\right.$, at $25^{\circ} \mathrm{C}$ and $\mathrm{pH}$ 7) catalyzed by L-asparaginase (L-asnase) and glutamate dehydrogenase (GDH) for various L-asparagine concentrations

\begin{tabular}{|c|c|c|c|c|}
\hline \multirow{2}{*}{$\begin{array}{l}\text { Proportion of L-asnase:GDH } \\
\text { in coimmobilized derivative }\end{array}$} & \multirow{2}{*}{$\begin{array}{l}\text { Amount of coimmobilized derivative } \\
\text { used to perform reaction }\end{array}$} & \multicolumn{3}{|c|}{ Concentration of L-asparagine (mM) } \\
\hline & & 0.55 & 1.1 & 2.2 \\
\hline \multirow[t]{2}{*}{$1: 1$} & $50 \mu \mathrm{L}$ & 0.0015 & 0.0700 & 0.0009 \\
\hline & $100 \mu \mathrm{L}$ & 0.0048 & 0.1184 & 0.0021 \\
\hline \multirow[t]{2}{*}{$1: 5$} & $50 \mu \mathrm{L}$ & 0.0153 & 0.1765 & 0.0203 \\
\hline & $100 \mu \mathrm{L}$ & 0.0399 & 0.3119 & 0.0509 \\
\hline \multirow[t]{2}{*}{$1: 20$} & $50 \mu \mathrm{L}$ & 0.0329 & 0.1001 & 0.0548 \\
\hline & $100 \mu \mathrm{L}$ & 0.0658 & 0.1913 & 0.1072 \\
\hline \multirow[t]{2}{*}{$1: 100$} & $50 \mu \mathrm{L}$ & 0.0541 & 0.0424 & 0.0573 \\
\hline & $100 \mu \mathrm{L}$ & 0.0908 & 0.0835 & 0.1012 \\
\hline
\end{tabular}

Note: The reaction mixture encompassed $2 \mathrm{~mL}$ of a $50 \mathrm{mM}\left(\mathrm{pH}\right.$ 7) $\mathrm{NaH}_{2} \mathrm{PO}_{4}$ solution, that is $0.11 \mathrm{mM}$ in $\alpha$-ketoglutarate and $0.5 \mathrm{mM}$ in $\beta$-NADH. 
4.0d. Performance of coimmobilized enzymes. The results, in the form of remaining $\beta$-NADH concentration, obtained for the batch hydrolysis of L-asparagine using coimmobilized derivatives of L-asparaginase and glutamate dehydrogenase, are displayed in Figure 3a for the 1:1 proportion of the former to the latter enzyme, in Figure $3 b$ for the 1:5 proportion, in Figure $3 \mathrm{c}$ for the 1:20 proportion, and in Figure $3 \mathrm{~d}$ for the 1:100 proportion.

4.0e. Separate immobilization versus coimmobilization. When comparing immobilization versus coimmobilization in different supports, important differences may be noticed, viz. in the induction period (i.e. the time for attainment of the maximum reaction rate) of ammonia production and also in the maximum reaction rate. Adding increasing amounts of independent glutamate dehydrogenase derivative to a fixed (small) amount of independent L-asparaginase derivative (see Figure 2a) had virtually no effect on the aforementioned induction period; however, when the amount of L-asparaginase was increased 7.5-fold, significant differences in said induction period arose (see Figure $2 b)$. Nevertheless, the efficiency of the independent enzyme derivatives was quite small. When the enzymes were coimmobilized onto the same agarose-glutaraldehyde support, their efficiency became three-fold higher (see Figures 3a, b, c, d).

As can be observed from inspection of Table 1, the rate of reaction becomes essentially independent of the concentration of L-asparagine when the proportion of glutamate dehydrogenase in the coimmobilized derivative is 100 -fold that of L-asparaginase; the induction periods necessary for ammonia production are also drastically reduced. The concentration of L-asparagine in the reaction medium seems to have an important effect in the rate of reaction (see Table 3); glutamate dehydrogenase is somehow inhibited at higher concentrations of L-asparagine (see Table 3), because the maximum reaction rate is always achieved at a concentration of L-asparagine of $1.1 \mathrm{mM}$.

The results obtained in the coimmobilization experiments suggest that each agarose bead containing both enzymes coimmobilized can be viewed as an integrated nanoreactor, with in situ reaction and separation of products (via elimination of ammonia). By using agarose (cross-linked to $4 \%$ ) activated with glutaraldehyde as support for coimmobilization, the (nano)environment surrounding each molecule of enzyme is virtually devoid of steric hindrance. When separate derivatives were utilized to perform that reaction, the ammonia produced inside the pores of the L-asparaginase derivatives needs to diffuse out of the agarose beads into the reaction medium, and diffuse back into the agarose beads containing immobilized glutamate dehydrogenase. However, when both enzymes were coimmobilized onto the same support, this sequence of steps was drastically reduced, as the ammonia produced inside the pores by the first immobilized enzyme becomes immediately accessible to the second immobilized enzyme. Two immediate advan- tages of this (entropically favored) approach are (i) the shortening of the induction periods and (ii) the enhancement of the effectiveness of the immobilized particles, with concomitant increase in the maximum reaction rate.

\section{Acknowledgements}

Financial support for VMB through a Postdoctoral fellowship by FCT (PRAXIS XXI BPD/16388/98) is hereby gratefully acknowledged.

\section{References}

[1] Oettgen HF, Old LJ, Boyse EA, Campbell HA, Philips FS, Clarkson BD, Tallal L, Leeper RD, Schwartz MK, Kim JH. Inhibition of leukemias in man by L-asparaginase. Cancer Res 1967;27:2619-31.

[2] Ohnuma T, Holland JF, Freeman A, Sinks LF. Biochemical and pharmacological studies with asparaginase in man. Cancer Res 1970; 30:2297-305.

[3] Epp O, Steigemann W, Formanek H, Huber R. Crystallographic evidence for the tetrameric subunit structure of L-asparaginase from Escherichia coli. Eur J Biochem 1971;20:432-7.

[4] Asselin BL, Lorenson MY, Whitin JC, Coppola DJ, Kende AS, Blakeley RL, Cohen HJ. Measurement of serum L-asparagine in the presence of L-asparaginase requires the presence of an L-asparaginase inhibitor. Cancer Res 1991;51:6568-73.

[5] Story MD, Voehringer DW, Stephens LC, Meyn RE. L-asparaginase kills lymphoma cells by apoptosis. Cancer Chemoter Pharmacol 1993;32:129-33.

[6] Kodera Y, Sekine T, Yasukohchi T, Kiriu Y, Hiroto M, Matsushima A, Inada Y. Stabilization of L-asparaginase modified with combshaped poly(ethylene glycol) derivatives, in vivo and in vitro. Bioconjugate Chem 1994;5:283-6.

[7] Gaspar MM, Perez-Soler R, Cruz MEM. Biological characterization of L-asparaginase liposomal formulations. Cancer Chemoter Pharmacol 1996;38:373-7.

[8] Jean-François J, Fortier G. Immobilization of L-asparaginase into a biocompatible poly(ethylene glycol)-albumin hydrogel: I: preparation and in vitro characterization. Biotechnol Appl Biochem 1996;23: $221-6$.

[9] Kravtzoff R, Desbois I, Lamagnere JP, Muh JP, Valat C, Chassaigne M, Colombat P, Ropars C. Improved pharmacodynamics of L-asparaginase loaded in human red blood cells. Eur J Clin Pharmacol 1996;49:465-70.

[10] Lubkowski J, Palm GJ, Gilliland GL, Derst C, Röhm K-H, Wlodawer A. Crystal structure and amino acid sequence of Wolinella succinogenes L-asparaginase. Eur J Biochem 1996;241:201-7.

[11] Martins MBAF, Gonçalves APV, Cruz MEM. Biochemical characterization of an L-asparaginase bioconjugate. Bioconjugate Chem 1996;7:430-5.

[12] Fernandes AI, Gregoriadis G. Polysialylated asparaginase: preparation, activity and pharmacokinetics. Biochim Biophys Acta 1997; 1341:26-34.

[13] Jean-François J, D’Urso EM, Fortier G. Immobilization of L-asparaginase into a biocompatible poly(ethylene glycol)-albumin hydrogel: evaluation of performance in vivo. Biotechnol Appl Biochem 1997; 26:203-12.

[14] Swain AL, Jaskolski M, Housset D, Mohana Rao JK, Wlodawer A. Crystal structure of Escherichia coli L-asparaginase, an enzyme used in cancer therapy. Proc Natl Acad Sci USA 1993;90:1474-8.

[15] Manna S, Sinha A, Sadhukhan R, Chakrabarty SL. Purification, characterization and antitumor activity of $\mathrm{L}$-asparaginase isolated from Pseudomonas stutzeri MB-405. Curr Microbiol 1995;30:291-8. 
[16] Peterson PE, Pierce J, Smith TJ. Crystallization and characterization of bovine liver glutamate dehydrogenase. J Struct Biol 1997;120: 73-7.

[17] Bailey JE, Ollis DF. Biochemical Engineering Fundamentals. McGraw-Hill, New York, U.S.A. 1986.

[18] Hill CG. An Introduction to Chemical Engineering Kinetics and Reactor Design. Wiley, New York, U.S.A. 1977.

[19] Bernstein H, Wheatley MA, Langer RS. Extracorporeal reactors containing immobilized species. U.S. Patent no. 4,863,611. 1989.

[20] Minim LA, Filho RM. Modelling and adaptive control of L-asparaginase reactor. Computers Chem Eng 1994;18(suppl):S693-7.

[21] Guisán JM. Aldehyde-agarose gels as activated supports for immobilization-stabilization of enzymes. Enz Microb Technol 1988;10: 375-82.

[22] Guisán JM, Blanco RM, Fernández-Lafuente R, Rosell CM, Alvaro G, Bastida A. Enzyme stabilization by multipoint covalent attachment to activated pre-existing supports. In: Protein Stability and Stabilization. WJJ van den Tweel, A Harder and RM Buitelaar (Eds), Elsevier, 1993, 55-62.

[23] Medin AS. Studies on Structure and Properties of Agarose. Ph.D. thesis 1995, Uppsala University, Uppsala, Sweden.

[24] Penzol G, Armisén PA, Fernández-Lafuente R, Rodés L, Guisán JM. Use of dextrans as long and hydrophilic spacer arms to improve the performance of immobilized proteins acting on macromolecules. Biotechnol Bioeng 1998;60:518-23.
[25] Fernández-Lafuente R, Guisán JM. Enzyme and protein engineering via immobilization and post-immobilization techniques. Recent Res Devel Biotechnol Bioeng 1998;1:299-309.

[26] Fernández-Lafuente R, Rosell CM, Rodriguez V, Guisán JM. Strategies for enzyme stabilization by intramolecular cross-linking with bifunctional reagents. Enz Microb Technol 1995;17:517-23.

[27] Fernández-Lafuente R, Rodriguez V, Mateo C, Penzol G, HernandezJustiz O, Irazoqui G, Villarino A, Ovsejevi K, Batista F, Guisan JM. Stabilization of multimeric enzymes via immobilization and postimmobilization techniques. J Mol Catal B: Enzymatic 1999a;7:181-9.

[28] Fernández-Lafuente R, Rosell CM, Caanan-Haden L, Rodés L, Guisán JM. Facile synthesis of artificial enzyme nano-environments via solid-phase chemistry of immobilized derivatives: dramatic stabilization of penicillin acylase versus organic solvents. Enz Microb Technol 1999b;24:96-103.

[29] Balcão VM, Mateo C, Fernández-Lafuente R, Malcata FX, Guisán JM. Structural and functional stabilization of L-asparaginase via multi-subunit immobilization onto highly activated supports. Biotechnol Prog 2001 [in press].

[30] Blanco RM, Calvete JJ, Guisán JM. Immobilization-stabilization of enzymes; variables that control the intensity of the trypsin (amino)agarose (aldehyde) multipoint attachment. Enz Microb Technol 1989; 11:353-9.

[31] Blanco RM, Guisán JM. Stabilization of enzymes by multipoint covalent attachment to agarose-aldehyde gels: Borohydride reduction of trypsin-agarose derivatives. Enz Microb Technol 1989;11:360-6. 